\title{
HEIDEGGER E A FILOSOFIA DO SALTO
}

HEIDEGGER AND THE PHILOSOPHY OF THE LEAP

\author{
RODRIGO AMORIM CASTELO BRANCO 1 \\ Universidade de Brasília (UnB) - Brasil \\ rodrigocasbranco@gmail.com
}

\begin{abstract}
RESUMO: O intuito deste texto é fazer uma abordagem fenomenológica a respeito da terceira juntura (Fügung) das Contribuições à filosofia (Do acontecimento apropriador). Buscamos discutir de que modo o salto (der Sprung) é uma forma de passagem do primeiro princípio do pensamento (filosofia como metafísica) ao outro princípio do pensamento (meditação filosófica acolhedora do ser (Seyn) em seu profundo velamento). O salto é irrepresentável, não é passível de ser modulado por nenhum cálculo ou representação do ente, uma vez que saltar, segundo as meditações de Heidegger, indica lançar-se em uma via totalmente outra do percurso ôntico seguido pela metafísica em toda a história ocidental. O salto é o deslocamento do ser-aí (Da-sein) da zona da entidade rumo ao acolhimento da recusa do ser. Nesse sentido, o ser-aí recepciona o fundamento na sua mais singela e profunda vigência, isto é, como o Nada do ente e como fosso abissal ( $A b$-grund).
\end{abstract}

PALAVRAS-CHAVE: Heidegger. Salto. Ser. Ser-aí. Nada.

ABSTRACT: The purpose of this text is to make a phenomenological approach to the third juncture (Fügung) of Contributions to philosophy (Of the Event). We seek to discuss how the leap (der Sprung) is a form of transition from the first principle of thought (philosophy as metaphysics) to the other principle of thought (welcoming philosophical meditation of being (Seyn) in its profound veiling). The leap is unrepresentable; it cannot be modulated by any calculation or representation of the entity, since leaping, according to Heidegger's meditations, indicates launching into a path totally different from the ontic path followed by metaphysics throughout Western history. The leap is the displacement of the being-there (Da-sein) from the zone of the entity towards the acceptance of the refusal of being. In this sense, the being-there receives the foundation in its simplest and most profound validity, that is, as the Nothing of the entity and as abyssal moat (Ab-grund).

KEYWORDS: Heidegger. Leap. Being. Being-there. Nothing.

\section{CONSIDERAÇÕES INICIAIS}

Este trabalho demarca o salto (der Sprung) como questão fundamental a ser discutida durante todo o percurso do texto. Escolhe-se essa temática porque se trata da juntura (Fügung) essencial meditada por Heidegger nas Contribuições à filosofia (Do acontecimento apropriador) [Beiträge zur Philosophie (Vom Ereignis), 1936-38, GA 65], que permite mirar, originariamente, o primeiro princípio do pensamento como metafísica, este calcado em elementos como presença, entidade, representação e maquinação.

\footnotetext{
${ }^{1}$ Doutorando em Filosofia na Universidade de Brasília (UnB).
} 
O salto, aqui meditado, indica a possibilidade do ser, por si mesmo, doarse ao ente, deslocando-o do mundo do nivelamento técnico-metafísico. Nesse sentido, as reflexões deste texto visam, a partir das meditações de Heidegger, discutir acerca do grau de estranheza que o ser gera no ente por ser abismal, vindo à tona em caráter de Nada anulador (nichtiges Nichts). O que é anulado não é o homem: a sua maquinação (conceituação) é o que se torna falível perante o Nada. Importa dizer, a partir desse anúncio, que saltar significa rumar para um modo cuidadoso de acolhimento do mistério irrepresentável que o Ocidente, durante milênios, não experienciou, dado que esteve retido no mundo da presença. Fica esclarecido, assim, que o outro pensamento que Heidegger busca (o pensar que salta) não é uma continuidade da Mesmidade (estar em meio ao ente total e em suas representações). O referido autor tenta a via fenomenológica que deixa o fundamento se doar e trazer uma dádiva ao ente humano: o simples pensar, de outro modo, além da representação ôntica.

A obra de Heidegger que mais auxilia nas reflexões aqui propostas tem como título, em tradução portuguesa, Contribuições à filosofia. Ela declara que o salto é um evento da história do ser (Geschichte des Seyns) que se dá ao ser-aí (Da-sein) e que desponta para a transição do primeiro princípio (filosofia como metafísica) à profundidade abismal do outro princípio do pensamento (meditação que acolhe o ser (Seyn $)^{2}$ em seu singelo velamento). Isso significa que o homem ingressa em um momento que até então não tinha se dado na história. Ele se encontra em uma instância inteiramente distinta das épocas que já ocorreram.

Nessas considerações iniciais, indica-se um certo cuidado. Que não se confunda salto como fim abrupto da metafísica, isto é, como fim imediato do primeiro princípio (der erste Anfang), porque este ainda estará presente por certo tempo na transição e, possivelmente, até mesmo no outro princípio (der andere Anfang). O que está em processo de transição é desconhecido, pois se trata de um princípio não elucidado pela racionalidade, e tampouco se dá como um evento humano. Assim, todos aqueles muito "próximos da vida", como diz Heidegger, não pressentirão ou compreenderão o advir do ser (Seyn), dado que o vitalismo, o biologismo, o antropologismo, o tecnicismo e tantos outros vários -ismos nos quais o homem está inserido ainda obstruem e interditarão o espaço para o acontecimento apropriador, isto é, para o Nada. De toda forma, o ser acontece e apropria o homem, este queira ou não, uma vez que aquilo que não lhe convém chega, o perpassa, porque a essência, anuncia Heidegger, é vizinha e íntima do ser-aí (Da-sein). Tal intimidade é a questão discutida na primeira seção deste trabalho, ingressando e sendo debatida, também, nas partes subsequentes deste texto.

\footnotetext{
${ }^{2}$ Não escrevemos Sein, mas Seyn como "y" para indicar que o ser do qual falamos é o fundamento diverso de qualquer representação ôntica. Seyn, portanto, é o Nada do ente que não se deixa calcular por predicações. Na língua inglesa, assim como no idioma alemão, substitui-se a vogal "i" pelo "y" para grafar o ser como beyng. No português, Marco Antônio Casanova traduz Seyn por "seer" em Contribuições à filosofia (Do acontecimento apropriador). No artigo aqui em questão, decidimos continuar com a palavra ser em sua forma usual no português, mas sempre nos referindo à total diferença ontológica e abismal entre ser e ente. Nas citações, claro, mantivemos a grafia "seer" do tradutor.
} 


\section{O Nada (SEYN) SE AVIZINHA AO SER-Aí (DA-SEIN)}

Podemos iniciar esta seção do trabalho anunciando que o salto é a mais pura intimidade do ser (Seyn) com o ser-aí (Da-sein). É no salto, este evento impossível de ser mensurado ou calculado pelo "poder" representativo da razão, que o Nada se avizinha e o ser-aí pode se tornar o seu preservador. Suspende-se, nessa perspectiva, qualquer vontade de domínio sobre o mistério escapante do ser, desejo este de cálculo que perdurou durante séculos no Ocidente desde a filosofia platônica.

A questão precípua da transição ao salto é a preparação para a de-cisão (Entscheidung) fundamental, haja vista que se trata de uma mudança de rumos e de outra estruturação de mundo não condicionada pela vontade de poder humana. Trata-se do ou-ou do qual o homem não pode se desviar, porque o evento do ser que se apropria dos entes na história atual não deixa restar esconderijos ou regiões para desvios. O não-desvio do ou-ou acontece porque a nadificação do ser, isto é, a sua essenciação atinge o homem, fazendo-o se posicionar, de uma forma ou de outra. Nesse sentido, o ente humano decide porque foi arrebatado pela doação fundamental do ser. Aqui emerge a de-cisão geradora de uma cisão ou não. Não há cisão se o homem insistir no primeiro princípio em que impera a metafísica. A de-cisão se dá entre dois caminhos: ou se estabiliza no processo de modulação metafísica ou, seguindo outro caminhar, ruma-se ao outro princípio e decide-se pela sua paulatina e longa preparação. Trata-se de "um salto da confrontação (conexão de jogo) com o primeiro início ${ }^{3}$ e sua história” (HEIDEGGER, 2015, p. 226).

A história da metafísica (die Geschichte der Metaphysik), entendida por Heidegger como a história do primeiro princípio (die Geschichte des ersten Anfangs), "experiencia" o ser como essentia, í ća (idéa), isto é, como o a priorio extra-fundante, o que há de mais vigente. A essência, amiúde sob a égide do conceito, foi compreendida a partir da entidade do ente. Ela, ao mesmo tempo em que ser esteve "além" do ente, tornou-se o mais comum e o mais conhecido, porque foi re-presentada como o absoluto pela tradição filosófica. Nos diversos posicionamentos ontológicos dos ocidentais, o ser esteve a serviço do ente como a causa prima passível de ser conhecida. Em perspectiva de virada e de mirada originária na "relação" com o ser, Heidegger anuncia, nas Contribuições à filosofia, o outro princípio do pensar (andere Anfang) no qual o ser-aí (Da-sein) é aquele que não mais violenta o fundamento com modulações, mas é aquele que suporta a clareira (Seyn) na qual, desde sempre e de novo, está imerso serenamente. Esta clareira vige como Lichtung, que se encobre no seu modo de Ereignis. O ente já não tem mais a primazia, porque "No outro início, todo ente é sacrificado pelo seer $^{4}$ e, a partir daí, o ente enquanto tal obtém, pela primeira vez, a sua verdade"

\footnotetext{
${ }^{3}$ Marco Antônio Casanova traduz os termos der erste Anfang da obra Beiträge zur Philosophie por "primeiro início". No entanto, optamos pela tradução "primeiro princípio" durante todo o artigo, já que Heidegger diferencia início (Beginn) de princípio (Anfang). Anfang indica o instante principial que funda épocas e permanece vigente na história. Beginn evidencia o momento inicial de um caminho já principiado. Do mesmo modo, traduzimos der andere Anfang por "outro princípio".

${ }^{4}$ Como salientamos anteriormente, Marco Antônio Casanova traduz Seyn por seer nas Contribuições à filosofia.
} 
(HEIDEGGER, 2015, p. 226). Eis, aqui, o grande salto: o ente que está ingresso na dimensão da senda originária não por vontade de poder, mas por convocação do ser mesmo.

Heidegger é um pensador vinculado ao outro princípio do pensamento. A metafísica que investigou o ente enquanto ente não meditou sobre a não-entidade do fundamento. Nesse sentido, o ser não-ôntico anunciado por Heidegger é visto como um mistério, uma estranheza pela ontologia tradicional e por toda e qualquer forma de maquinação5 (Machenschaft) acostumada ao mundo da presença. Mas por que tal estranhamento na juntura (Fügung) do salto? Gadamer nos auxilia a compreender essa questão:

O logos não pode mais ser pensado como tornar aquilo que está presente manifesto, o "ser" não mais como algo supremo ou inferior presente e como algo presente para si mesmo. Ao contrário, o ser não é nada assente, no-thing [...] Isso implica que o "mundo" não seja, então, a totalidade de todo ente [...] Ele [ser-aí] é muito mais um projeto jogado antecipativamente a si mesmo, ser como tempo (GADAMER, 2007, p. 36).

A filosofia do salto, em Heidegger, declara que o "saltar" não está situado na mera de-cisão do próprio homem em, na época em que se encontra, acolher o ser como não-ente. É a própria essência que se re-vela como não-ôntica. Esse modo de des-velamento e acolhimento do ser indica a "saída" do horizonte das modulações metafísicas. A racionalidade da tradição, a respeito do entendimento de ser, não é suficiente para a meditação acerca do salto (Sprung). Enquanto a tradição entende o ser como presença manifesta ou como entidade superior, as Contribuições à filosofia e a indicação de Gadamer meditam sobre o ser (Seyn) como não-coisa, não-ente, não-objeto, no-thing, ni-enté . Assim, o mundo histórico e o próprio homem não são a partir do reino do ente. Pelo contrário, "o mundo munda" (die Welt weltet) porque o acontecimento vigente (Ereignis) abre a história e, a partir disso, o ser-aí conquista o seu ser-si-mesmo como guardião (Wächter), acolhedor da verdade do ser e, a cada vez, é um projeto lançado no tempo, no mundo que munda para os entes. Em prisma fenomenológico heideggeriano, o salto é um acontecimento que a lógica científica não consegue tratar com a devida deferência, tendo-se em vista que ele escapa ao domínio do ente. Esse evento fundante é o modo de nadificação do próprio ser, que passa ao largo de preceitos dados à mão.

\footnotetext{
${ }^{5}$ Machenschaft é traduzida por maquinação. Tal termo almeja trazer à tona o mundo da totalidade do ente, inserido na totalização do real, isto é, na dimensão da "fazeção", da factibilidade constante na qual o Ocidente está inserido em contraposição ao silêncio e à quietude de uma espera sem expectativa.

${ }^{6}$ De acordo com o texto Antologia Bilíngue, em língua italiana, "Para a negação se usa: nulla, no, niente, né [nada, não, nada, nem] (2012, p. 67). Como se pode notar, niente é traduzido, em português, por nada. Quando fazemos a relação do termo com o ser, em perspectiva heideggeriana, queremos demonstrar que o fundamento é nulo, é ileso à metafísica, porque não pode ser presenciado ou representado. Nessa chave de leitura, fazemos uma espécie de jogo linguístico com o termo ni-ente para anunciar ser como nada, ausente de conteúdo, não-dado, enfim, como o que escapa à totalidade do ente.
} 
No parágrafo anterior foi dito que o ser-aí conquista a sua singularidade no salto. É um ponto crucial na filosofia de Heidegger não identificar ser-aí com o homem. Ao humano pode ser permitido ser-aí na medida em que ele se converte em guardião do ser, ou seja, quando não rejeita a suspensão de si em meio ao Nada. No texto O que é a metafísica? [Was ist Metaphysik?, 1929, in Wegmarken, 1919-1961, GA 9] Heidegger elucida essa questão significativamente (2008, p. 125): "Ser-aí quer dizer: estar suspenso dentro do nada. Retendo-se no nada, o ser-aí está sempre para além do ente na totalidade. Esse estar para além do ente, nós designamos a transcendência”. Ser para além do ente na totalidade significa ser-aí, transcender o mundo do nivelamento cotidiano. Ser-aí, portanto, insinua uma abertura aos toques do Nada, pensamento acolhedor este que o homem da maquinação desconhece.

Aquele que acolhe o principial pode se singularizar. Aqui reside a abertura para o acontecimento apropriador (Ereignis), que prenuncia a prontidão ao silêncio e à quietude, modos pelos quais o ser-aí mais pode recepcionar o que ele não pode calcular. Trata-se do próprio destino do ser se dando na dimensão dos entes. Quanto a essa questão, Heidegger pronuncia, na conferência O princípio do fundamento [Der Satz vom Grund, 1955-56, GA 10]:

Na medida em que o destino do ser toma a essência pensante do homem histórico na reivindicação destinável, apoia-se a história do pensamento no destino do ser [...] O destino do ser permanece, em si, a história essencial do homem ocidental, na medida em que o homem histórico é necessário no habitar edificante da clareira do ser (HEIDEGGER, 1999, p. 137).

Note-se como no salto não é o homem que salta. Acontece, de modo enigmático, que o ser salta, isto é, atravessa e toma a consciência do ser-aí, conduzindo-o ao pensamento. É o que Heidegger chama de reivindicação destinável, já que o acontecimento apropriador funda a historicidade, a estrutura de uma época e, assim, singulariza os humanos. Nessa ótica, para o autor, a história do Ocidente é a história do ser em seus envios essenciais para apropriar a vida. Essa visita ontológica indica que o ente não pode ser explicado e derivado a partir de uma entidade dada. O homem só pode ser compreendido e fundado a partir da verdade do ser.

Embora a destinação do ser seja reivindicar o homem, incumbindo-o na existência, fortuitamente este último avança no caminho do ponto fulcral dessa verdade. Isso se dá porque facilmente a humanidade se deixa satisfazer pelas modulações ônticas, sendo desapropriada do fundamento. Mas Heidegger insiste (2015, p. 230) que a transição, o salto como "transposição para a essência do seer", é distinta de todo acesso representativo do ente. A verdade, assim, só pode viger na insistência do ser-aí, na experiência do caráter de lançado no aí (Da), onde ocorre o acontecimento apropriador. É na temporalidade do ser-aí em que se doam os sentidos fundamentais da existência.

É na temporalidade do ser-aí que há em vista a unidade essencialmente originária do acometimento extasiante manifesto como clareira e, ao mesmo 
tempo, como velamento, oferecendo o fundamento mais próximo para a fundação do ser-aí. "O tempo aqui [...] possui um significado completamente diverso, a saber, o significado da fundação dos sítios abertos da instantaneidade para um ser histórico do homem" (HEIDEGGER, 2015, p. 231). Mas, antes, a meditação aqui em vigor por Heidegger busca a permissão para um espaço de de-cisão (Entscheidung). O homem precisa experimentar a ausência de indigência (Not der Notlösigkeit) para compreender de que forma o ser o abandona e de que modo ele abandona o ser quando se petrifica na maquinação, isto é, na técnica. Esse espaço técnico do ente permite - compreendido em termos da própria história do ser em seu primeiro princípio - o abandono do ser e a elevação da carência de indigência.

O salto como o avizinhamento originário, que pode romper com a carência de indigência do ente, não implica na divulgação de novas doutrinas para promover o progresso das engrenagens humanas ao ápice da evolução da cultura e de seus valores. Mais profundamente, zela-se por um deslocamento radical do homem ao interior de sua pobreza (Armut), a fim de que ele visualize a indigência na qual, desde sempre, esteve contido.

Na meditação 120 das Contribuições o salto indica - para clarear a condição do homem situado na carência de indigência - que o fundamento não é ôntico. No entanto, o ente nunca ficou aquém ou além do ser, posto que já se decidiu pela essenciação do acontecimento primordial. Isso significa que o homem, em todas as suas de-cisões, esteve imerso no aberto essenciante. Por isso o salto: "O re-saltar da prontidão para o pertencimento ao acontecimento apropriador" (HEIDEGGER, 2015, p. 232). É aqui, nesse sítio clareante-ocultante que é possível compreender a acessibilidade (Zugänglichkeit) e a constância da abertura do fosso abismal (Ab-grund) no ser-aí (Da-sein). O ente só se torna histórico graças à apropriação por meio do evento nadificador que exige, de uma forma ou de outra, o ser-aí como suporte de doação. Mas por que a apropriação do ser é um evento originário em recusa (nadificado)? Para Heidegger, é justo esse caráter niilista do ser que o torna livre perante as re-presentações do ente. O ser como Nada não pode ser dominado (presenciado). A perspectiva do não domínio é o que faz ser "vir" como recusa. O saltar do ente implica em reconhecer que o ser avizinhado é escapante, estando sempre longínquo.

O salto faz com que se experimente, na história do Ocidente, a urgência de um outro modo de pensar que se subtraia às representações do ente. Poucos são os que chegam a essa altitude. E se o permitem fazê-lo, esses raros saltam por sendas distintas. Essa vereda transitiva é o que permite a fundação e o sacrífico do ser-aí. O ente renuncia ao seu "poder" de judicação para poder guardar, com deferência, os traços ontológicos provocados pela apropriação originária. A senda a partir da qual o ser acontece em intenso velamento, em um enlevo extasiante profundo traz à tona uma singularidade não-maquinal que permite a diferença. Trata-se do arrebatamento (Entrückung) abissal do Nada re-velador. Nesse sentido, salienta Heidegger:

Clareira e encobrimento, constituindo a essenciação da verdade, nunca podem, por isso, ser considerados como um transcurso vazio 
e como objeto do "conhecimento", de uma representação. Clareira e encobrimento são arrebatadores, de maneira extasiante, que voltam para o interior do próprio acontecimento apropriador (HEIDEGGER, 2015, p. 233).

O salto é o estranho caminho para dentro do sítio do acontecimento fundamental, dessa clareira (Lichtung) que se encobre. Não é o homem que vai para este "dentro": ele é lançado nesse meio inabitual. Trata-se de uma balança que pesa para o imponderável, que coloca o sendo do ente (contíguo e habitual) no antes nunca experienciado. O salto é um direcionamento para as veredas mais misteriosas, silenciosas e estranhas a serem "vistas" pelo homem, a fim de inclinálo para fora do habitual das metas e dos propósitos da cotidianidade. O saltar indica o próprio afetamento da verdade do ser como abertura de possibilidades históricas, de tal forma que o ser-aí, que está nessa conexão de jogo, no passe do primeiro princípio ao outro princípio do pensar, joga o projeto dessa verdade como projeto lançado (Geworfenheit), como aquele que é fundado pelo deixar-ser do fundamento. É nesse lançamento que o ser-aí pode experimentar a essenciação como abertura originária e se tornar partícipe do mistério.

Segundo Heidegger, o caráter de lançado do ser-aí só pode vir à tona nos acontecimentos fundamentais da história encoberta, quando o homem se perceber como indigente por estar perante o Nada do ser, o que o fará sentir a necessidade da de-cisão pelo não-necessário. Acontece que aquele que está em conexão de jogo (entre metafísica e salto no ser), originariamente, é jogado e projetado, é fundado e realizado. "Na medida em que aquele que joga, projeta, fala de maneira pensante 'sobre o acontecimento apropriador', desentranha-se o fato de que ele mesmo, quanto mais projetante ele se torna, tanto mais jogado aquele que é jogado já é" (HEIDEGGER, 2015, p. 236). Ora, aqui se aprofunda a meditação de que o ser-aí nada mais realiza autonomamente. O que ele possibilita, na sua facticidade de jogador jogado, é partir para se tornar si mesmo: "o que guarda o projeto jogado, o fundador fundado do fundamento" (HEIDEGGER, 2015, p. 236, grifos do autor). Quanto mais o ser-aí joga o jogo da verdade, sendo interpelado a saltar e salta, mais se vincula, adentra e se mistura a uma vigência ontológica.

Por que acontece o adentrar de uma instância (ser/Seyn) na outra (seraí/Da-sein)? Heidegger toca na questão do comum-pertencimento entre ambos e o fragmento textual de Luciana Ferreira esclarece essa questão:

Para o ente humano, o seu ser não é senão um poder-ser e, portanto, possibilidades. Assim, o ser não possui a forma de uma identidade [...] Pura abertura de possibilidades, o ser é ausência um nada significante que fala, por meio do ente, os seus modos próprios. Embora diferentes, ser e ente se copertencem, ou seja, partilham a possibilidade do comum-acontecimento sem que um se identifique com o outro - o ente na luz e pela luz do ser, o ser na expressão do ente. Ambos íntimos e, contemporaneamente, distintos (FERREIRA, 2010, p. 41, grifos da autora). 
O ser é compreendido como o aberto que se essencia. É justamente por isso que ele não tem identidade, por ser pura abertura de possibilidades não calculadas ou determinadas. Trata-se de um Nada fundante, que muito diz por meio do ente, no entanto, aos seus próprios modos. É esse copertencer (zusammengehören), essa partilha que possibilita com que ser se anuncie no seraí, sem, com isso, haver identificação entre o fundador e o fundado. Acontece que o homem é aquele que é clareado pela essenciação originária e, assim, pode se expressar. Há uma intimidade entre as duas esferas, mas em cada época em que o principial se dá, a diferença ontológica é o que marca a íntima relação entre ser (Seyn) e ser-aí (Da-sein). No acontecimento apropriador há o estremecimento insondável que acontece quando o fundamento, em recusa, adentra no ente. O ser mesmo estremece e arrebata o ente com o seu dizer essenciante.

O sentido do ser como recusa não deve nos inclinar a pensá-lo como simples recuo de uma partida iniciada. Contrariamente a isso, a recusa fundamental é a intimidade que atribui e demanda a vida. No estremecimento causado pelo fundamento, é atribuído ao ser-aí (Da-sein) se lançar no mundo para ser fundado essencialmente. É desse modo que o ente é convocado à verdade, é escalado originariamente. "O homem é requisitado por meio dessa requisição do próprio seer como o guardião da verdade do seer (ser homem como 'cuidado', fundado no ser-aí)" (HEIDEGGER, 2015, p. 237). A recusa ontológica é um modo próprio de convocação profunda do ser, que anuncia e aponta para a necessidade de enraizamento no elementar.

O "ser é como a recusa atributiva, o acontecimento da apropriação do serấ” (HEIDEGGER, 2015, p. 237). Esta meditação aqui anunciada faz ver como a fenomenologia heideggeriana é um manancial de ambiguidades. O caráter ambíguo dessa filosofia não traz dano ou perda de sentido. Pelo contrário, permite significados para além das modulações ônticas, técnicas ou calculantes. O pensamento de Heidegger acerca da vigência do ser tenta meditar sobre o principial de forma não-representativa, isto é, não violenta. A ambiguidade aqui se encontra nas palavras "recusa atributiva", buscando pensar sobre o modo peculiar do acontecimento apropriador. Aqui surge a grande aporia em que a lógica ou a ciência não conseguem adentrar, uma vez que a essência que se apropria do homem rompe com o recorte racional do mundo maquinal. A técnica não entende como o ser pode perpassar a existência como recusa. Isso é ilógico e impossível para ela. Mas o que Heidegger quer dizer é: a nadificação do ser (sua recusa essencial) é o modo pelo qual o Nada mais apropria e atribui (demanda) o ente.

Apropriação aqui se entende como evento que gera guarda, que faz ver o ser-aí como a (de)morada do fundamento. O cuidado (Sorge) do ser-aí precisa edificar, cuidar do inabitual e da simplicidade reluzentes. A mediação metafísica, que busca se posicionar determinantemente acerca do ser, não tem tal cuidado. Ela, ao cercear o ente à zona da subjetividade, propicia, ainda mais profundamente, o abandono do ser (Seinsverlassenheit) e, com isso, há o maior esquecimento do sublime na era da maquinação, onde o cálculo se torna a própria verdade. Por isso, para Heidegger (2015, p. 237), a necessidade da viragem, posto que "É 
somente por meio da queda e da reviravolta do ente que o ente bifurcado em maquinação e vivência e já calcificado [...] chega a ceder diante do seer".

Cuidado implica em aguardar o envio insigne. De acordo com Heidegger, esse envio se dá atributivamente como retração, que apela ao silêncio, no qual a sua verdade pode ser compreendida como a clareira para o velamento. O desvelarse é o desencobrimento da recusa, pois indica o seu próprio modo de se dar no mundo: uma doação retraída. Por isso, o acontecimento apropriador (Ereignis) é um evento estranho do outro princípio, porque, na medida em que acontece na história, prenuncia-se, convoca o homem, mas essa requisição parte de um não, de um chamado invisível ao olhar maquinal, um Nada fundamental que muito fala, mas que raros o escutam.

A grande questão aqui é a ousadia do ente, suportada pela tonalidade afetiva essencial (Grundstimmung) da retenção (Verhaltenheit), a partir da qual o reconhecimento da pobreza e, consequentemente, da indigência ontológica, provocaria, nesse ente, o estímulo para o acolhimento da "voz" não-maquinal. Dessa forma, haveria espaço para o arrebatamento extasiante, que clareia o ser-aí, indicando, a ele, caminhos e possibilidades. Como essa vigência originária não pode ser comprovada por sistemas científicos, pelas induções e deduções do ente, ela é vista como um nada sem sentido. Por outro lado, Heidegger pensa tal vigor primordial, que funda entes e épocas, não apenas como algo que tem sentido, mas como a origem sustentadora de todos os significados da existência.

Heidegger apresenta, nas Contribuições à filosofia, a noção de extração acometedora $^{7}$, que se dá àquele que se torna insistente (força) a ponto de pensar o originário e que possui seriedade para decidir e cindir a caminho de um outro princípio da história. Força e seriedade aqui não podem ser entendidos como o que se depara com a noção de bom e mau, derrocada ou redenção da tradição, filantropia ou hostilidade. Em outro horizonte de pensamento, Heidegger quer demonstrar que a inessência vigora como essencialmente necessária. A saída do inessencial (maquinação) está em direção ao mistério do ser a partir da força e da seriedade (cuidado e guarda) do ser-aí. O pensador anuncia:

Ser e tempo não é nenhum "ideal" e nenhum "programa", mas o início que se prepara da essenciação do seer mesmo; não aquilo que nós repensamos, mas o que, contanto que tenhamos nos tornado suficientemente maduros, nos impõe a entrada em um pensar que nem fornece uma "existência", mas que, ao contrário, "apenas" funda a verdade como o campo de jogo temporal no qual o ente uma vez mais pode ser sendo, isto é, pode se transformar na guarda do seer (HEIDEGGER, 2015, p. 239).

O prenúncio da abertura do ser em Ser e tempo, essa questão tão meditada nas Contribuições à filosofia, não é fruto de uma receita bem construída da

\footnotetext{
${ }^{7}$ Termo presente na seção 125 Ser e tempo das Contribuições, p. 239. Trata-se de um acometimento originário e fundamental do ser (Seyn), que permite ao ente acolher e hospedar uma outra tração, uma tração extasiante. Assim, ele pode se repensar como projeto lançado, eks-tático em meio a possibilidades. É nessa forma de apropriação que o ser-aí passa a ver o mundo e a si mesmo a partir do mistério da essenciação do ser.
} 
subjetividade da vontade, tampouco pode ser dita por um programa de pesquisa ou por um sistema: é um aceno do ser (Seyn) em sua própria vigência. É a maturidade do ser-aí, cunhada pela serenidade (Gelassenheit), que o permite reconhecer a sua indigência perante o Nada que o funda. Tal reconhecimento é o que faz do ser-aí o custódio (Wahrer) do fundamento.

Como vimos até aqui, a "relação" entre ser e ente é de complexa abordagem porque se trata de um copertencimento em choque - eclosão, mas retração do fundamento (ser) no ente fundado. Esse comum pertencimento, no primeiro princípio do pensar, foi visto sob a ótica ôntica, onde o ser se tornou a entidade máxima produtora do real. Todavia, aqui acontece um desvio acerca da questão do ser (Seynsfrage), pois, como afirma Heidegger (2015, p. 240, grifo do autor): "O seer só alcança sua grandeza se ele é reconhecido como aquilo de que o deus dos deuses e de que toda deização precisam". Ora, o historicamente "usado" ("ser" como entidade), no salto, opõe-se a toda utilização, dado que, anterior a qualquer posição metafísica que queira definir um ente supremo como causa prima, o acontecimento apropriador acomete os "fundadores" de deuses.

O salto meditado por Heidegger é para o interior do abandono do ser que, no primeiro princípio, permaneceu inquestionado. Elucida-se a abertura do fosso abissal como o desdobramento da intimidade do ser com o ente, na medida em que todo ente o experimenta como recusa. A recusa aqui se dá por meio da vigência principial, esse evento que provoca, em termos kierkergaardianos, temor e tremor ${ }^{8}$, o estremecimento essencial a partir do momento em que ser ou o Nada se apropria da vida. No entanto, como o ente pode compreender esse Nada? É possível experienciá-lo, sendo que, do nada, nada emerge, como disseram os primeiros gregos? Heidegger (2015, p. 241, grifos do autor) nos responde: podemos compreender o Nada "Como o excesso da pura recusa. Quanto mais rico o 'nada', tanto mais simples o seer". O Nada aqui não deve ser entendido na dimensão da nadificação vazia, pelo contrário, cuida-se para compreendê-lo como o que, em sua abundante recusa, a sua simplicidade diz e anuncia com fartura de sentidos, que podem ser escutados pelo mais profundo silêncio. Reiteramos: o Nada é a significância mais elevada, que muito se pronuncia na quietude. Acerca do dizer da quietude, Heidegger evidencia, no texto $A$ caminho da linguagem [Unterwegs zur Sprache, 1950-59, GA 12]:

A consonância do quieto não é nada humano. Ao contrário. Em sua essência, o homem é como linguagem. A expressão "como linguagem" diz aqui: o que se apropria pelo falar da linguagem. $\mathrm{O}$ que se apropria, a essência do homem, é trazido pela linguagem ao seu próprio de maneira a permanecer uma propriedade da essência da linguagem, ou seja, da consonância do quieto. Essa apropriação se apropria à medida em que a essência da linguagem, a consonância do quieto, faz uso da fala dos mortais, no intuito de torná-la sonora como consonância do quieto para a escuta dos mortais. Somente porque os homens pertencem à consonância do quieto, os mortais têm a capacidade de, a seu modo, falar emitindo sons (HEIDEGGER, 2003, p. 24, grifos do autor).

${ }^{8}$ Cfr. KIERKEGAARD, Søren. Temor e tremor. São Paulo: Abril Cultural, 1979. 
Essencialmente, o ente humano é linguagem e só pode expressá-la porque, antes de tudo, é hermeneuta, naturalmente intérprete do mundo circundante repleto de significados. Contudo, por que o homem pode interpretar? De onde advém a fonte de suas interpretações? Qual é o fundamento hermenêutico que o torna um hermeneuta? Justamente o que não é humano é o que humaniza o homem, fazendo dele um ser imbuído de sentidos a serem expressos. A linguagem, embora expressa pelo ente, só pode vir à tona porque esta entra em intimidade, em consonância com a quietude (recusa originária), que se essencia entre os mortais. A linguagem é um modo do acontecimento apropriador que se dá ao homem, para que este, ao seu próprio modo, possa se pronunciar. Os mortais dizem porque o não-dito advém, eles expressam sentidos e significados, porque são guardas do mistério e, desse modo, a essência da linguagem os acomete de forma vigorosa. Surgem edificações semânticas e hermenêuticas no mundo a partir do evento fundamental que se chama acontecimento apropriador (Ereignis). É aqui que há o pressentimento do ser (Ahnung des Seyns), porque este se apropria profundamente do homem. O acontecimento apropriador necessita de um sipróprio, de um si mesmo, isto é, daquele que pode sustentar, insistentemente, a simplicidade silenciosa do dizer primordial.

Na próxima seção deste artigo, o escopo é discutir justamente acerca do apelo essenciante que convoca o ente, deslocando-o da unidimensionalidade do real. A argumentação, a seguir, gira em torno do advir ontológico nulificador (ser em caráter não representativo) que incumbe o ser-aí à proteção da verdade, ou seja, que o torna defensor do Nada frente às maquinações de um mundo técnico, o qual podemos chamar de esfera do sim, da correção e da certeza do ego.

\section{O SER (NADA) SE DOA EM APELO AO ENIE E NÃO SEM ELE}

$\mathrm{Na}$ seção anterior foi exposto, a partir da meditação de Heidegger sobre a juntura do salto, que o Nada se avizinha na temporalidade do ente. O que se busca refletir nesse momento de discussão é o porquê desse avizinhamento nadificante. Uma resposta simples, que será retomada durante toda esta fase do texto, revelase: o Nada não acontece sem o elemento ôntico chamado ente.

O ser "é visto" a partir do ente, mas não é o ente. Aquilo que "não é", é, de acordo com o pensamento nivelado do cotidiano, o nada. Essa posição negativista do nada o nulifica pejorativamente, tomando-o como um vazio que deve ser rejeitado. Nessa concepção habitual, não se vê a copertinência entre ser e Nada de forma mais originária. Ora, se o ser mesmo é o que se subtrai e se essencia como recusa, é isso que permite a singela nulidade, a insigne doação do fundamento. É por meio dessa negatividade do ser que o Nada ganha a plena consistência de todo criar. No entanto, se o sim da factibilidade e das vivências define a realidade do ente, o não da negação é reprovado pela entidade. Seria, dessa forma, o sim corrente se elevando e emprestando medida a todo não. Mas a viragem do pensamento, nas Contribuiçôes à filosofia, não almeja continuar no asseguramento do sim da tradição ontológica, pelo contrário, tem como escopo a apresentação 
do acontecimento apropriador fundante do ser-aí, este pertencente à verdade (clareira ocultante), que é a essência própria do ser.

$\mathrm{Na}$ viragem do pensar das Contribuiçôes à filosofia, emerge a essência originária que pensa o verdadeiro e, também, o ente. Nesse outro caminhar meditativo, o ser advém ao modo de um salto para o ente e essa experiência transmuta as antigas referências tidas acerca da entidade. Por conseguinte, o ser-aí e os raros de seu traço são levados a se posicionar a partir da instância do mistério para "fundarem" outra história. Mas que história é essa? Uma história do ser em caráter nulo para o ente e que provoque efeitos no ente. Nesse sentido, Heidegger diz:

\begin{abstract}
Não é possível calcular se terá sucesso esse revolvimento do homem até aqui, isto é, a fundação anterior da verdade mais originária no ente de uma nova história. Ao contrário, tudo depende da doação ou da subtração do próprio acontecimento da apropriação; e isso mesmo se a essenciação do seer já tiver previamente pensada na meditação atual e se ela tiver se tornado consciente nos seus traços fundamentais (HEIDEGGER, 2015, p. 244).
\end{abstract}

Como o salto para o outro princípio não pode ser previsto por um sistema ou programa que gere uma receita precisa de como se dará a história vindoura, não há certeza alguma sobre o que acontecerá a partir do revolvimento do homem à guarda da verdade. E como a origem de todo sendo do ente está referida à própria abertura do ser, em doação velada do acontecimento apropriador não humano, a racionalidade não pode precisar esse evento essencial. Tal acontecimento apropriador que funda o aí ( $D a$ ) exige que aquele que pode ser acometido pela essenciação dessa apropriação vá ao encontro dessa abertura. Trata-se de uma recepção humana ao toque inumano para se sair do estado atual maquinal, que nega a história do ser e que o esquece fixamente. É por isso que o deslocamento do homem, essa ida ao encontro do fundamento exige a mais intensa diligência para a verdade, solicita-se presteza frente a essência do verdadeiro. Deve surgir a prontidão para recusar os esteios fixos nos domínios da correção e da reificação maquinais e, assim, o ente não será mais o normativo para o ser. Faz-se mister, para Heidegger, o lançamento do pensamento tão para o interior do aí, que a verdade do ser passe a se clarear originariamente.

Embora ser e ente permaneçam copertencentes, no salto, o primeiro continua estranho ao segundo e a fundação da verdade do ser eleva ainda mais a sua estranheza, fazendo desse fundamento um solo estrangeiro ao ente graças à diferença ontológica entre ambos. A distinção aqui acontece porque há a medida excessiva na essência do ser, que não indica nenhuma demasia ou imoderação, mas demonstra o subtrair-se a toda avaliação e cálculo no qual o entitativo se pauta para o "progresso". "A medida excessiva não é, naturalmente, o além de um suprasensível, mas, enquanto acontecimento da apropriação, a coação do ente" (HEIDEGGER, 2015, p. 245). Heidegger não pensa essa medida como qualificação do superior sobre o inferior na categoria de nivelamento ou de hierarquização, por

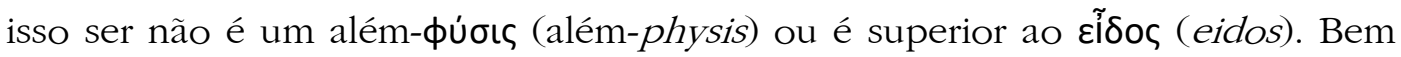


mais profundo do que essa noção, trata-se do acontecimento fundamental que constrange e impele o ente a ser si mesmo no próprio plano da imanência, no âmbito mesmo finito e pobre da conjuntura humana.

O que a medida excessiva deixa acontecer é a subtração da mensuração, permitindo a abertura do espaço contencioso entre ser e ente, no qual se dá o encobrir-se do fundamento em toda retenção ôntica, pois é desse modo que o seraí pertence, originariamente, ao seu apropriador. Dá-se o acontecimento da apropriação, esse subtrair-se (sich entziehen) que se entrega. Ele se oferece como uma dádiva vigencial, um encobrimento carecedor de guarda. O ser carece do ente para que se essencie e, intimamente, o ente se afina (pertence) ao ser. É nessa afinação que o homem se consuma enquanto ser-aí. Esse pensamento se confirma quando, na preleção O tempo da imagem do mundo [Die Zeit des Weltbildes, 1938, GA 5], Heidegger (1998, p. 93) declara a importante passagem: "[...] o ser é apelo [Zuspruch] aos homens e não é sem eles".

Acontece que há um impulso recíproco do carecer e do pertencer mesmo onde há a diferenciação na diferença ontológica, que assegura a verdade do ser diante de toda mistura com o mundo vitalista do ente. A diferenciação apresentada em Ser e tempo [Sein und Zeit, 1927, GA 2], nesse sentido, apela para a recusa do hábito de objetivação que buscamos instaurar acerca da essenciação do ser. Solicita-se, dessa forma, o recuo do hábito que, arbitrariamente, busca representar o principial. Daí a força do salto para que o ser-aí proteja a oscilação no seu pleno vir em retiro. Assim, Ser e tempo começa a evidenciar que, de modo algum podemos alcançar o derradeiro, o absoluto, mas temos a possibilidade de saltar para o de-cisivo, para a mais profunda essenciação silenciosa. Tal anúncio demonstra o abismal da finitude como a grande vereda do fundamento que nos fundamenta, como a amplitude aberta do acontecimento que de nós se apropria. Vê-se que há "unicidade do seer (como acontecimento apropriador), a irrepresentabilidade (nenhum objeto), a mais elevada estranheza e o essencial encobrir-se" (HEIDEGGER, 2015, p. 248, grifos do autor).

Se desconsideramos o caráter estranho e unitário do ser, desconhecemos a sua incomparabilidade com o ente e, a partir disso, podemos cair no mundo das modulações modernas, que traz a noção dual entre sujeito e objeto. Mas, na tonalidade afetiva fundamental da retenção (Grundstimmung der Verhaltenheit), o ente pode escutar o silêncio ressonante do mistério, este que supera a subjetividade como o aspecto fundante do humano, que suplanta, igualmente, a perspectiva de ser como mero objeto representável contraposto ao sujeito que o representa. Assim, para Heidegger, o ser-aí é aquele que custodia a doação do ser (Geschenk des Seyns) e a compreende em sua estranheza e unicidade. Aqui, só há essa compreensão fundamental porque a questão acerca da verdade do ser é renunciada como mero cálculo do ego.

A vigência do acontecimento fundante encerra em si o evento da apropriação a partir do qual o ser-aí é afinado e, nessa apropriação, acontece a sua fundação. No entanto, esse discurso não pode induzir ao erro e deixar sugerir que o ser se essencia por si só enquanto o ser-aí acolheria essa essenciação realizada em uma ligação com o ser. "A ligação do ser-aí com o seer pertence à 
essenciação do próprio seer" (HEIDEGGER, 2015, p. 250, grifos do autor). Isto é, a ligação do ser-aí é com o ser (Seyn), tendo em vista que essa essência não se doa de forma alguma sem o carecedor que permita o acontecimento apropriador. A essenciação do ser é do ser, mas na zona do ente. Essenciação indica a íntima ressonância do fundamento a partir da retenção do fundado.

Como o ser é o que há de mais raro e único, o ente não tem a capacidade de apreciar os pontos instantes nos quais ele gera sendas e funda, para si, um sítio de essenciação. Todavia, essa afirmação não significa que o ente perde firmeza. Ele ainda está no âmbito de de-cisão a fim de se converter em destinatário das doações ontológicas. Como expõe Heidegger:

A experiência do seer, o suportar a sua verdade, traz [...] o ente de volta para as suas barreiras e retira dele a aparente unicidade de seu primado. No entanto, assim ele não se torna menos assente, mas, ao contrário, mais assente, mais essencial na essenciação do seer (HEIDEGGER, 2015, p. 251).

É a doação do ser, não decidida pelo ente, que revela a amplitude de possibilidades na qual o ser-aí é inserido a cada abertura de senda essenciante. No outro princípio que agora se prenuncia no pensar heideggeriano, a estranheza do ser em sua própria essenciação deve ser alcançada como elemento principial e essencial. O ser não é o familiar (representado), não é visualizado como uma determinação maximamente assente e universal; não se identifica como gênero superior, não é causa que completa o ente; não é o amplo componente que se encontra aquém ou além do ente, tampouco é um adendo ou adorno de qualquer entidade. Nas meditações de Heidegger, o fundamento é a essenciação - verdade pertinente como encobrimento-clareador -, que se desvela no abrigo do ente, tornando-o existente. É por meio da morada originária que emerge, historicamente, o ente e a verdade do ser é guardada na insistência do ser-aí em relação ao aberto. Aqui é levado a termo a ligação entre ser-aí e o fundamento. Esse evento acontece no tempo-espaço, no aí (Da) do ser-aí (Da-sein), onde há a região querelante, porque quando ser se dá no ente, emerge daí o arrebatamento (Entrückung) extasiante e reluzente da verdade.

Se a história do primeiro princípio é a história do Ocidente na normatividade da interpretação do ente, que define o tempo como presentidade e o espaço como lugar, como o aqui e o lá, Heidegger compreende tempo-espaço como a região na qual há a reunião fugidia entre ser e ser-aí. É no tempo-espaço "onde" acontece o apelo. A verdade do ser só pode viger onde e quando se dá o ser-aí. O ser-aí é o onde e o quando do qual o fundamento se apropria. "O acontecimento apropriador funda, em si, o ser-aí. O ser-aí funda o acontecimento apropriador" (HEIDEGGER, 2015, p. 257). Essa junção e os dois mesmos só se tornam íntimos e acessíveis no Ereignis.

O ser vige no tempo-espaço como o entre (zwischen), que jamais pode ser fundado no ente presentificado, mas apenas se funda no ser-aí. Aquele que, insistentemente está para a verdade, está como ser-aí no mundo. Ser-no-mundo (in-der-Welt-sein) não indica que é pela graça do homem que o fundamento se 
essencia. Acontece que ser se doa na medida em que o ser-aí é acenado para se tornar o guardião da verdade. Eis o sítio contencioso em virtude da intimidade do não do ser. É da doação primordial, do não originário que ocorre a intimidade com o fundado (ser-aí). Eis o paradoxo, a ambiguidade fundamental em Heidegger: é esse insistente que, quanto mais originariamente se torna singular, mais abundantemente se volta para fora (para além do seu ego calculante). Sempre e de novo está em meio à vigência principial e é fundado pela eclosão do que há de mais singelo. Logo, o íntimo fundamento é o aberto que, por mais que não seja humano, carece do ser-aí para se doar.

Quando falamos em doação do ser (Seyn), referimo-nos, outrossim, à convocação do Nada. Essa questão não indica que o Nada seja negativo no sentido habitual do termo. De outra forma, a nadificação aqui indica o próprio estremecimento fundamental do ser. É por esse motivo que é tão penoso, nos tempos de hoje, o desprendimento do pensar tradicional do Ocidente, que entende o Nada a partir da instância da qualificação e da hierarquização, não percebendo que ele "é" mais insigne do que o "positivo" e o "negativo" da zona do ente. O questionar pensante só pode bem indagar acerca dessa questão se se lançar na originariedade que vá além da confiança nos sistemas e nos dispositivos calculantes modernos. Assim, o homem, para saltar rumo ao outro princípio deve

[...] ser forte o suficiente para experimentar o elemento niilizador no próprio seer, que nos es-panta como a mais velada doação. Nesse caso, então, reconhece-se que o nada jamais se deixa computar e calcular contra o seer, porque o seer (e isto significa o nada) é o entrementes para o ente e para a deização e nunca pode se tornar "meta" (HEIDEGGER, 2015, p. 262, grifos do autor).

Depreende-se da indicação que o não do ser rompe com o conceito comum de vazio (perda, ausência do objeto desejado). A niilização fundamental - a dotação do caráter de não do ser - em hipótese alguma indica o Nada como se este fosse um representado, que diz: o Nada não é, porque não está (não é algo). Na visão de Heidegger, o Nada não é, porque não é ente. O não principial é nadificação de si, que se subtrai ao cômputo da maquinação. Ele pertencente à essência do acontecimento apropriador e tal acontecimento pertence ao não. Tendo-se isso em vista, o ser se essencia não sendo ente, mas se dá no ente como renúncia hesitante, como generosidade de um não que possibilita multiplicidade de sentidos. A maturidade do ser-aí espera pelo não originário, pois é a partir desse evento niilizante que o ser se essencia ao modo de Ereignis, deixando e fazendo ver novas possibilidades de ser-no-mundo. O maduro é sensato, é sereno. Essa serenidade, se podemos nomeá-la, cuidadosamente arriscamos dizer que ela é poesia.

Maduro é aquele está aberto ao abismo (Abgrund), à verdade mais rara e singela. Para Heidegger, Hölderlin estaria ingresso na maturidade, uma vez que versa e poetiza assumindo os seus limites de homem e, por conseguinte, as possibilidades que advêm do que o ente não pode calcular. $\mathrm{O}$ abismo acolhido tanto por Hölderlin como por Heidegger é o tempo-espaço do ser, é a sua vigência 
mesma no acontecimento apropriador. O abissal entra em copertencimento ao seraí. É nesse aí (tempo-espaço do ente) onde se dá o sítio acontecencial e onde o ser-aí, insistente na essenciação, é apropriado em meio ao acometimento do aberto. Todavia, para isso, o ente necessita ser recuperado de uma moléstia: a vontade metafísica de domínio sobre o real. A simplicidade, a partir da quebra com a prepotência (Übermacht) do homem, pode se clarear. Mas o simples só pode ser "avistado" na medida em que o deixamos ser livremente, sem a procura de clareza e de evidência.

No incalculável do acontecimento apropriador, o ser-aí é fundado abissalmente e lançado na sua mais íntima finitude. Aqui acontece, apropriadoramente, a ausência, o velamento acometedor como o dar-se radical do fundamento. Por parte do ente, há retenção da ressonância e a liberdade do acolhimento. Isso sinaliza que o ser não precisa de poder compulsório ou de qualquer tipo de violência para acometer o ente. A sua essenciação permanece mais fundadora do que a ação pelos moldes da força.

O poder é a possibilidade do acesso a uma posse por meio da força. A violência é uma irrupção de poder que visa transformar o ente pelo ente. No entanto, poder e violência buscam acessar posses e transformar realidades sem o salto à interioridade da abertura originária, porque estão amplamente no íntimo da maquinação. Como salienta Heidegger (2015, p. 277): "Por toda parte, onde o ente deve ser alterado pelo ente (não a partir do seer), a violência é necessária. Todo ato é um ato violento, de tal modo que aqui a violência é dominada em consonância com o poder".

O salto visa trazer à tona uma filosofia da não-violência ao demonstrar que a estranheza do ser reside no fato de não estar acessível ao domínio do ente. O homem analisa esse "estranho outro" com olhos irados, porque não pode cerceálo pela representação. Essa inabitualidade reside no estranhamento que o incomum (Seyn) mesmo deixar aparecer. O evento fundante é único, inabitual e ininteligível à vontade de cálculo do ente. O mistério da clareira surge com agudeza única. É somente ao ser-aí - a esse transformado naquele que procura e que guarda o fundamental - que a verdade primeva, essa estranheza, pode se fundar. "Na inabitualidade e na unicidade [...] abre-se o que há de mais inabitual em todo ente, o próprio seer, que se essencia como estranhamento" (HEIDEGGER, 2015, p. 278).

Para ser possível o pressentimento da originariedade a partir do habitual (ente), faz-se mister que o ser-aí esteja aberto a possibilidades, a nadificações não previstas. Essa abertura não pode ser compreendida como o alcance do Nada, mas, de outro modo, trata-se de acolher os encaminhamentos que o ser pode "indicar". Aqui a subjetividade perde sua força, é passiva diante do mistério essenciante. A reflexão fenomenológica de Heidegger, como se vê, como mirada originária sobre o que nos singulariza na existência, passa ao largo de termos morais e valorativos, considerando-se a questão sobre o ser a partir do vir-ir-embora do ser mesmo.

A nossa discussão demonstrou que o ser-aí é fundamentado pelo que constantemente se retrai. Isso indica que ele é um ser para o Nada, aqui residindo a sua essência. No entanto, o importante não é diluir o ser do ente no Nada e 
determiná-lo como uma simples nulidade. Aqui se busca demonstrar como a ausência apropriadora está intimamente ligada ao ser-aí para evidenciar as possibilidades do projeto humano. O Nada, como salienta Ramos (2015, p. 320), "não é irremovível aguilhão, mas justamente aquilo que remove o humano do domínio das presenças, no sentido usual de efetividade, e o faz revolver-se para aquela ausência, a essencial nulidade do ser (Seyn)". Nesse sentido, é insistindo na estranheza do ser que o ser-aí concede espaço à abertura do fundamento, tornando-se o lugar maduro para o desvelamento da essência originária. Havendo essa intimidade nulificadora entre Nada e ente, há, pois, o salto em vista.

\section{CONSIDERAÇÕES FINAIS}

O percurso de reflexão até aqui teve como questão central discutir o salto em Heidegger como o deslocamento que atinge o ser-aí a partir de um mistério donativo (Nada anulador). Houve a tentativa de demonstrar que o salto instaura a possibilidade de que o ente reconheça a sua finitude perante o ser que o funda a cada vez. Por vias fenomenológicas, discutiu-se o quanto as maquinações humanas, não reconhecedoras de sua finitude, passam ao largo da essenciação do Nada, pois esta não se identifica a qualquer predicação, uma vez que é estranha à técnica e, portanto, ilesa à representação. O ser, nesse sentido, como diferença originária, está fora do panorama lógico-conceitual do ente e de seus artifícios por ser abissal, o fundamento nulo que faz a história seguir seus próprios e peculiares caminhos.

Explicou-se a tarefa do salto, o impulso para a viragem do pensamento em deferência à essenciação do ser no ente, este último como o sítio no qual o fundamento se dá como clareira (Lichtung). O salto, nas meditações de Heidegger, passa a ser "visto" como o acontecimento essencial para o interior do ser-aí (Dasein) por meio da apropriação do homem, fazendo-o ter conhecimento da vigência ontológica do Nada. Embora o vigor do ser não possa ser representado, ele só pode ser experienciado quando o seu mistério perpassa a existência. Em outros termos, no salto reside o "contato" com o elementar. A apropriação se torna o "lugar temporal", âmbito no qual o ser-aí custodia o acontecimento que se dá no outro princípio do pensar. Trata-se de um evento vigoroso que impacta e estremece o tempo-espaço $(\mathrm{Da} / \mathrm{a}$ İ do ente e, de súbito, recolhe-se. É justamente o recolhimento do ser e apenas a acolhida de sua recusa que deixa a entidade sendo, não podendo apreender a essência por objetivações, mensurações e por táticas de controle. O salto quer demonstrar a fenda abissal na qual se encontra o homem, este sustentado no Nada. O Nada aqui, além de representar o fundamento como não-ente, é o modo do ser se essenciar, dado que permanece vigorando em subtração, vigendo como recusa.

Dito de modo mais claro, o Nada, a recusa do ser é uma retirada que deixa o ser-aí a-fundamentado (facticamente lançado na existência), todavia, com rastros que o permitem se situar no mundo. Em seu velamento, o ser se oculta, mas, ao mesmo tempo, deixa um traço ontológico de possibilidades que podem fazer do ser-aí um ser histórico. É justo o acolhimento do mistério em caráter de ausência 
que permite ao Da-sein ser-si-mesmo, isto é, elevar-se à singularidade criativa. Nesse sentido, pode-se dizer que, nas meditações de Heidegger, a doação fundamental do Nada passa a ter mais robustez do que qualquer presença ôntica que se encontra nas representações da cotidianidade média.

Se o que arrebata e funda o ser-aí é a robustez do Nada, então ele é lançado no mais profundo fosso abismal (Ab-grund). O fundamento é o abismo que acomete o ser-aí e o deixa perante o Nada, iluminado pela ausência elementar. Quando o ser-aí reconhece a finitude de sua facticidade, ele abre os olhos para a sua carência essencial: a sua necessidade do não-necessário, isto é, dos acenos e dos toques do ser para que tenha outras possibilidades de ser-no-mundo, possibilidades estas distintas da violência do ente, diversas do poderio maquinal que a tudo busca modelar.

O que o homem parece necessitar é de paciência e de silêncio para custodiar a ressonância do Nada. O florescimento de outra postura no ente depende do reconhecimento de sua carência de ser. Heidegger anuncia, nas Contribuições à filosofia, a pobreza e a finitude do homem perante o seu fundamento. O referido autor traz à tona maturidade e serenidade meditativas que respeitam o ser como diferença e, por isso, podemos dizer que as suas reflexões podem nos inclinar, no desenvolvimento de outros trabalhos, a pensar uma filosofia da não-violência. Essa hipótese ocorre na medida em que o pensamento heideggeriano ultrapassa o mundo da prepotência representacional do ente, tendo como perspectiva o acolhimento do Nada. Esse ir além da violência ôntica indica o saltar no salto (essenciação) do ser.

\section{REFERÊNCIAS}

FERREIRA, Luciana da Silva Mendes. O "Outro" em Heidegger é o "Mesmo" em Lévinas?: uma defesa da alteridade na ontologia fundamental. Brasília: Universa, 2010 .

GADAMER, Hans-Georg. Fenomenologia, hermenêutica e metafísica. In: Hermenêutica em retrospectiva: vol. II - A virada hermenêutica. Petrópolis, RJ: Vozes, 2007.

HEIDEGGER, Martin. A linguagem. In: A caminho da linguagem. Petrópolis, RJ: Vozes; Bragança Paulista, SP: Editora Universitária São Francisco, 2003.

. O que é metafísica? In: Marcas do Caminho. Petrópolis, RJ: Vozes, 2008.

Contribuições à filosofia (Do acontecimento apropriador). Rio de Janeiro: Via Verita, 2015.

. O princípio do fundamento. Lisboa: Instituto Piaget, 1999.

- O tempo da imagem do mundo. In: Caminhos de Floresta: Lisboa: Fundação Calouste Gulbenkian, 1998.

RAMOS, Daniel Rodrigues. O Ereignis em Heidegger. Teresópolis: Daimon, 2015. 
ROMANELLI, Sérgio (Org.). Antologia Bilingue. Tubarão: Copiart; Florianópolis: PGET/UFSC, 2012.

Recebido em: 27-09-2019

Aceito para publicação em: 18-02-19 